\title{
Reclassification of Micrococcus agilis (Ali-Cohen 1889) to the Genus Arthrobacter as Arthrobacter agilis comb. nov. and Emendation of the Genus Arthrobacter
}

\author{
CATHRIN KOCH, ${ }^{1}$ PETER SCHUMANN,${ }^{2}$ AND ERKO STACKEBRANDT ${ }^{1 *}$ \\ DSM-German Collection of Microorganisms and Cell Cultures GmbH, 38124 Braunschweig, ${ }^{1}$ \\ and Beutenbergstrasse 11, 07708 Jena, ${ }^{2}$ Germany
}

\begin{abstract}
Phylogenetic evidence derived from a 16S ribosomal DNA analysis indicated that the type strain of Micrococcus agilis, DSM 20550 (= ATCC $966=$ CCM 2390), is less closely related to the type species of the genus Micrococcus, Micrococcus luteus, than to the type species of the genus Arthrobacter, Arthrobacter globiformis, and related Arthrobacter species. The phylogenetic position of $M$. agilis is supported by the presence of peptidoglycan variation $\mathrm{A} 3 \alpha$ and by the presence of MK-9 $\left(\mathrm{H}_{2}\right)$ as the major isoprenolog, a characteristic also found in strains of $A$. globiformis, Arthrobacter crystallopoietes, Arthrobacter atrocyaneus, Arthrobacter citreus, Arthrobacter aurescens, Arthrobacter ilicis, Arthrobacter ureafaciens, Arthrobacter oxydans, Arthrobacter histidinolovorans, and Arthrobacter nicotinovorans. The last six species and $M$. agilis are characterized by the presence of threonine in the interpeptide bridge of the peptidoglycan. Threonine has not been found in the peptidoglycans of other Arthrobacter species or in members of the genus Micrococcus. Despite the fact that a morphological life cycle is not known, these data support the proposal that $M$. agilis should be transferred to the genus Arthrobacter as Arthrobacter agilis comb. nov.
\end{abstract}

A recent phylogenetic analysis of the $16 \mathrm{~S}$ ribosomal DNAs (rDNAs) of the type strains of 15 species belonging to the genera Arthrobacter and Micrococcus indicated that three Micrococcus species (Micrococcus luteus, Micrococcus lylae, and Micrococcus agilis) should be placed within the radiation that contains members of the genus Arthrobacter, while the other Micrococcus species are more distantly related (7). The degrees of relatedness between $M$. agilis and certain members of the genus Arthrobacter were significantly higher than the degrees of relatedness between $M$. agilis and the other two $M i$ crococcus species and even between many Arthrobacter species. This result suggested that $M$. agilis is a member of the genus Arthrobacter sensu stricto (6), but that its development is blocked so that only one stage of the life cycle typical of Arthrobacter species is observed (18).

In order to place $M$. agilis more precisely within the radiation of the 16S rDNA tree, we extended the analysis to include all known type strains belonging to the genera Arthrobacter and Micrococcus. The $16 \mathrm{~S}$ rDNAs were analyzed as described previously (14). The inclusion of six Arthrobacter sequences which we determined, the sequences of Arthrobacter aurescens DSM $20116^{\mathrm{T}}$ ( $\mathrm{T}=$ type strain), Arthrobacter histidinolovorans DSM $20115^{\mathrm{T}}$, Arthrobacter ilicis DSM 20138 ${ }^{\mathrm{T}}$, Arthrobacter oxydans DSM $20119^{\mathrm{T}}$, Arthrobacter sulfureus DSM 20167 ${ }^{\mathrm{T}}$, and $A r$ throbacter uratoxydans DSM 20647 ${ }^{\mathrm{T}}$, and the sequences of other Micrococcus species (data not shown) did not significantly change the topology of the phylogenetic tree (17). The position of $M$. agilis (Fig. 1) indicates that this organism is a member of the Arthrobacter species group, as defined by peptidoglycan variation A $3 \alpha$, which contains Arthrobacter globiformis, the type species of the genus. This group is referred to as group I. The second recognized group of Arthrobacter species (group II) (i.e., species with peptidoglycan type A4 $\alpha$ ) appears to be more closely related to $M$. luteus and $M$. lylae. An analysis

* Corresponding author. Mailing address: DSM-German Collection of Microorganisms and Cell Cultures $\mathrm{GmbH}$, Mascheroder Weg 1b, 38124 Braunschweig, Germany. Phone: 495312616 352. Fax: 49531 2616 418. Electronic mail address: stackebrandt@venus.gbf-braun schweig.d400.de.

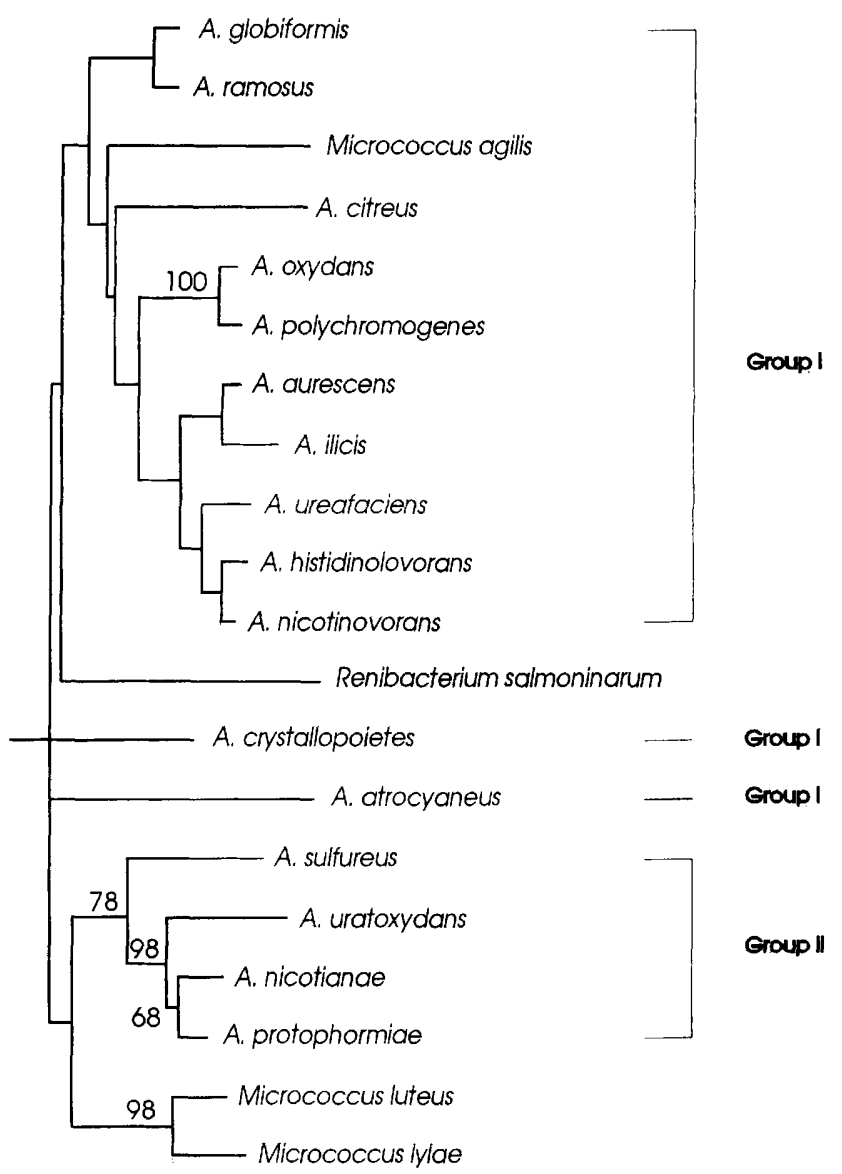

FIG. 1. Phylogenetic dendrogram based on a comparison of the 16S rDNA sequences of $M$. agilis and related organisms belonging to the genera Micrococcus, Arthrobacter, and Renibacterium. The branching pattern was generated as described previously (14). Numbers refer to bootstrap values. Bar $=1.5$ substitutions per 100 nucleotides. 
TABLE 1. Cell wall types, menaquinone compositions, and DNA G+C contents of $M$. agilis and phylogenetically related organisms belonging to the genera Arthrobacter, Micrococcus, and Renibacterium

\begin{tabular}{|c|c|c|c|c|c|}
\hline Organism & Group & $\begin{array}{l}\text { Peptidoglycan } \\
\text { variant }^{\prime \prime}\end{array}$ & $\begin{array}{l}\text { Peptidoglycan } \\
\text { type }^{b}\end{array}$ & $\begin{array}{c}\text { Major } \\
\text { isoprenolog(s) }\end{array}$ & $\begin{array}{l}\mathrm{G}+\mathrm{C} \text { content } \\
(\mathrm{mol} \%)^{d}\end{array}$ \\
\hline M. agilis & & $\mathrm{A} 3 \alpha$ & Lys-Thr-Ala 3 & MK-9 $\left(\mathrm{H}_{2}\right)$ & $67.0-70.0$ \\
\hline A. citreus & I & $\mathrm{A} 3 \alpha$ & Lys-Thr-Ala 2 & $\mathrm{MK}-9\left(\mathrm{H}_{2}\right)$ & $62.9-65.1$ \\
\hline A. oxydans & I & $\mathrm{A} 3 \alpha$ & Lys-Ser-Thr-Ala & MK-9 $\left(\mathrm{H}_{2}\right)$ & $62.7-65.9$ \\
\hline A. polychromogenes & I & $\mathrm{A} 3 \alpha$ & Lys-Ser-Thr-Ala & $\operatorname{MK}-9\left(\mathrm{H}_{2}\right)$ & 62.9 \\
\hline A. aurescens & I & $\mathrm{A} 3 \alpha$ & Lys-Ala-Thr-Ala & $\mathrm{MK}-9\left(\mathrm{H}_{2}\right)$ & $59.1-61.9$ \\
\hline A. ilicis & I & $\mathrm{A} 3 \alpha$ & Lys-Ala-Thr-Ala & $\mathrm{MK}-9\left(\mathrm{H}_{2}\right)$ & $60.0-61.5$ \\
\hline A. histidinolovorans & I & $\mathrm{A} 3 \alpha$ & Lys-Ala-Thr-Ala & MK-9 $\left(\mathrm{H}_{2}\right)$ & $61.3-62.2$ \\
\hline A. nicotinovorans ${ }^{e}$ & I & $\mathrm{A} 3 \alpha$ & Lys-Ala-Thr-Ala & $\mathrm{MK}-9\left(\mathrm{H}_{2}\right)$ & 62.4 \\
\hline A. globiformis & I & $\mathrm{A} 3 \alpha$ & Lys-Ala 3 & MK-9 $\left(\mathrm{H}_{2}\right)$ & $62.0-65.5$ \\
\hline A. ramosus & I & $\mathrm{A} 3 \alpha$ & Lys-Ala 4 & MK-9 $\left(\mathrm{H}_{2}\right)$ & $62.2-63.1$ \\
\hline A. crystallopoietes & I & $\mathrm{A} 3 \alpha$ & Lys-Ala & MK-9 $\left(\mathrm{H}_{2}\right)$ & $63.0-63.8$ \\
\hline A. atrocyaneus & I & $\mathrm{A} 3 \alpha$ & Lys-Ser-Ala $2-3$ & MK-9 $\left(\mathrm{H}_{2}\right)$ & $69.5-70.3$ \\
\hline R. salmoninarum ${ }^{f}$ & & $\mathrm{~A} 3 \alpha$ & Lys-Gly-Ala & MK-9, MK-10 & 53.0 \\
\hline A. sulfureus & II & $\mathrm{A} 4 \alpha$ & Lys-Glu & MK-9, MK-10 & $64.5-66.0$ \\
\hline A. protophormiae & II & $\mathrm{A} 4 \alpha$ & Lys-Ala-Glu & MK-9, MK-8 & $63.2-65.9$ \\
\hline M. luteus & & $\mathrm{A} 2$ & Lys-peptide subunit & $\mathrm{MK}-8^{h}$ & $70.0-75.5$ \\
\hline M. lylae & & $\mathrm{A} 3 \alpha$ & Lys-Asp & $\mathrm{MK}-8\left(\mathrm{H}_{2}\right)^{h}$ & $67.7-69.5$ \\
\hline
\end{tabular}

a As defined by Schleifer and Kandier (16).

DData from references 8 and 16.

Data from references 6, 8, and 19.

${ }^{a}$ Data from references 2,6 , and 8 .

'Data from reference 10.

${ }^{f}$ Data from references 11 and 15 .

${ }^{g} \mathrm{ND}$, not determined.

${ }^{h}$ Data from reference 17

of bootstrap values, however, indicated that most branching points could not be considered statistically significant, as most values were less than $50 \%$. The levels of sequence difference between most pairs of organisms shown in Fig. 1 are too small (between 0.5 and $6.0 \%$ ) to reliably determine the order in which these highly related species evolved.

Despite the low statistical significance of the tree topology, the clustering is by and large supported by the phenotypic data (Table 1). Not only is the separation of Arthrobacter species into groups I and II confirmed (5), but all species that contain threonine in the interpeptide bridge of peptidoglycan form a phylogenically coherent cluster within group I. M. agilis, like all other group I species, contains major amounts of isoprenoid quinones of the MK- $9\left(\mathrm{H}_{2}\right)$ type ( $>80 \%$ of the total quinones), while Arthrobacter group II species, Renibacterium salmoninarum, $M$. luteus, and $M$. lylae contain unsaturated menaquinones $(4,15)$. Group I and II organisms cannot be clearly distinguished on the basis of fatty acid spectra, because all members of the genus Arthrobacter produce similar patterns, consisting of major amounts of iso and anteiso methyl-branched acids and with smaller amounts of straight-chain fatty acids $(5,8$, 10). A similar pattern has been reported for the type strain of $M$. agilis (2; this study). Comparative studies performed with members of the genera Arthrobacter and Micrococcus are necessary to determine more precisely the levels of similarity among the fatty acid profiles of individual species. The polar lipid compositions of members of Arthrobacter groups I and II are similar $(2,3,5)$, but group I species and $M$. agilis contain phosphatidylinositol (5), which is not found in the other $\mathrm{Ar}$ throbacter species. The previously reported $\mathrm{G}+\mathrm{C}$ content of $M$. agilis DNA ranges from 67.0 to $70 \mathrm{~mol} \%(2,8)$, values which are in the same range as the values obtained for other Micrococcus species. Since the values for Arthrobacter species are generally about 2 to $3 \%$ lower than the values for micrococci, the $\mathrm{G}+\mathrm{C}$ content of $M$. agilis was redetermined by high-performance liquid chromatography (13). The value obtained was $69.5 \mathrm{~mol} \%$, which confirms the previously reported values.

$M$. agilis (1) and several Arthrobacter group I species, including Arthrobacter ramosus, A. ilicis, Arthrobacter citreus, and Arthrobacter atrocyaneus, are motile (5). It should be noted in this context that early descriptions of $M$. agilis indicated that motility is frequently lost in laboratory cultures (12); this could lead to classification of these red-pigmented organisms as color variants of the pastel-red- to orange-red-pigmented organism Micrococcus roseus (12). Decades later, strains of $M$. agilis deposited in the American Type Culture Collection (ATCC 98 and ATCC 9814) were also found to be nonmotile (9), and loss of motility by $M$. agilis strains has also been observed in the DSM-German Collection of Microorganisms (18a). Thus, in $M$. agilis motility is not a stable taxonomic marker.

M. agilis is related to Arthrobacter group I, and phylogenetic evidence and key chemotaxonomic characteristics indicate that M. agilis should be reclassified in the genus Arthrobacter as Arthrobacter agilis Ali-Cohen 1889. The transfer of a coccoid species to the genus Arthrobacter means that the genus description must be emended, as follows: a marked rod-coccus growth cycle occurs during growth in complex media; stationary-phase cultures (generally after 2 to 7 days) are composed entirely or largely of coccoid cells that are $\sim 0.6$ to $1.0 \mu \mathrm{m}$ in diameter; one species forms only spherical cells.

Description of Arthrobacter agilis (Ali-Cohen) comb. nov. The species description below is based on information derived from several sources $(2,8,9)$ and our own observations. Spheres that are 0.8 to $1.2 \mu \mathrm{m}$ in diameter occur in pairs and tetrads. Agar colonies are circular, entire, slightly convex, smooth, and matte. Sediment is formed in nutrient broth. No 
growth occurs on Simmons citrate medium. Good dark rosered-pigmented growth occurs on agar slants. The pigment is water insoluble.

Motile by means of one to three flagella. Nonmotile strains may occur. Spores are not formed. Gram positive.

The cell wall peptidoglycan type is type L-Lys-L-Thr-L-Ala (variation $\mathrm{A} 3 \alpha$ ). The predominant menaquinone isoprenolog is $\mathrm{MK}-9\left(\mathrm{H}_{2}\right)$; $\mathrm{MH}-8\left(\mathrm{H}_{2}\right)$ is a minor component. Contains major amounts of anteiso methyl-branched acids ( $\sim 65.5 \%$ anteiso- $\left.\mathrm{C}_{15: 0}\right)$ and smaller amounts of iso methyl-branched acids $\left(\sim 13 \%\right.$ iso- $\mathrm{C}_{15: 0}$ and $\sim 6 \%$ iso- $\left.\mathrm{C}_{16: 1}\right)$. The polar lipids are phosphatidylglycerol, diphosphatidylglycerol, phosphatidylinositol, and an unknown ninhydrin-negative glycolipid. The amino sugar in the cell wall polysaccharide is glucosamine.

Chemoorganotrophic. Metabolism is respiratory. Aerobic.

Acid and gas are not produced from glucose, mannose, lactose, galactose, and glycerol. Catalase positive. Porphyrin respiratory enzymes are produced. Oxidase positive. Acetylmethylcarbinol is not produced. $\beta$-Galactosidase ( $o$-nitrophenyl- $\beta$ D-galactopyranoside test) positive. Methyl red negative. Indole and hydrogen sulfide are not produced. Nitrate is not reduced. Gelatin, starch, and esculin are hydrolyzed. Arginine dihydrolase, ornithine and lysine decarboxylases, and phenylalanine deaminase are not produced. Tween 80 may be split. DNase may be produced. Urease, tyrosinase, and phosphatase are not produced.

Beta-hemolysis does not occur.

Good growth occurs at temperatures between 20 and $30^{\circ} \mathrm{C}$. No growth occurs at $37^{\circ} \mathrm{C}$.

No growth occurs on medium containing $5 \% \mathrm{NaCl}$.

Susceptible to penicillin, streptomycin, chloramphenicol, tetracycline, erythromycin, novobiocin, ampicillin, carbenicillin, and gentamicin. Resistant to lysozyme.

Saprophytic. Habitat: water, soil, and human skin.

The $\mathrm{G}+\mathrm{C}$ content of the DNA is 67.0 to $69.0 \mathrm{~mol} \%$.

Closely related phylogenetically to $A$. globiformis, $A$. ramosus, Arthrobacter pascens, A. citreus, A. oxydans, Arthrobacter polychromogenes, $A$. aurescens, A. ilicis, Arthrobacter ureafaciens, A. histidinolovorans, and Arthrobacter nicotinovorans as determined by a $16 \mathrm{~S}$ rDNA analysis.

The type strain is ATCC 966 (= DSM $20550=$ CCM 2390).

Nucleotide sequence accession numbers. The EMBL accession numbers for the $16 \mathrm{~S}$ rDNA sequences which we determined are as follows: $A$. aurescens DSM $20116^{\mathrm{T}}, \mathrm{X} 83405 ; A$. histidinolovorans DSM 20115 ${ }^{\mathrm{T}}$, X83406; . ilicis DSM 20138 ${ }^{\mathrm{T}}$, X83407; A. oxydans DSM 20119 ${ }^{\mathrm{T}}$, X83408; A . sulfureus DSM $20167^{\mathrm{T}}, \mathrm{X} 83409$; and $A$. uratoxydans $\mathrm{DSM} 20647^{\mathrm{T}}, \mathrm{X} 83410$.

We thank J. Burghardt for her assistance in the DNA base composition determination.

\section{REFERENCES}

1. Ali-Cohen, C. H. 1889. Eigenbewegung bei Mikrokokken. Zentralbl. Bakteriol. Parasitenkd. Infektionskr. Hyg. Abt. 1 Orig. 6:33-36.

2. Brooks, B. W., R. G. E. Murray, J. L. Johnson, E. Stackebrandt, C. R. Woese, and G. E. Fox. 1980. Red-pigmented micrococci: a basis for taxonomy. Int. J. Syst. Bacteriol. 30:627-646.

3. Collins, M. D. 1982. Lipid composition of Renibacterium salmoninarum (Sanders and Fryer). FEMS Microbiol. Lett. 13:295-297.

4. Jeffries, L., M. A. Cawthorne, M. Harris, B. Cook, and A. T. Diplock. 1969. Menaquinone determination in the taxonomy of Micrococcaceae. J. Gen. Microbiol. 54:365-380.

5. Keddie, R. M., M. D. Collins, and D. Jones. 1986. Genus Arthrobacter Conn and Dimmick $1947,300^{\text {AL }}$, p. 1228-1301. In P. H. A. Sneath, N. S. Mair, M. E. Sharpe, and J. G. Holt (ed.), Bergey's manual of systematic bacteriology, vol. 2. Williams and Wilkins, Baltimore.

6. Keddie, R. M., and D. Jones. 1981. Aerobic, saprophytic coryneform bacteria, p. 1838-1878. In M. P. Starr, H. Stolp, H. G. Trüper, A. Balows, and H. G. Schlegel (ed.), The prokaryotes. Springer Verlag, New York.

7. Koch, C., F. A. Rainey, and E. Stackebrandt. 1994. 16S rDNA studies on members of Arthrobacter and Micrococcus: an aid for their future taxonomic restructuring. FEMS Microbiol. Lett. 123:167-172.

8. Kocur, M. 1986. Micrococcus, p. 1004-1008. In P. H. A. Sneath, N. S. Mair, M. E. Sharpe, and J. G. Holt (ed.), Bergey's manual of systematic bacteriology, vol. 2. Williams and Wilkins, Baltimore.

9. Kocur, M., and K. H. Schleifer. 1975. Taxonomic status of Micrococcus agilis Ali-Cohen 1899. Int. J. Syst. Bacteriol. 25:294-297.

10. Kodama, Y., H. Yamamoto, N. Amano, and T. Amachi. 1992. Reclassification of two strains of Arthrobacter oxydans and proposal of Arthrobacter nicotinovorans sp. nov. Int. J. Syst. Bacteriol. 42:234-239.

11. Kusser, W., and F. Fiedler. 1983. Murein type and polysaccharide composition of cell walls from Renibacterium salmoninarum. FEMS Microbiol. Lett. 20:391-394.

12. Lehmann, K. B. L., and R. Neumann. 1899. Atlas und Grundriss der Bakteriologie. Lehmann, Munich.

13. Mesbah, M., U. Premachandran, and W. B. Whitman. 1989. Precise measurement of the $\mathrm{G}+\mathrm{C}$ content of deoxyribonucleic acid by high-performance liquid chromatography. Int. J. Syst. Bacteriol. 39:159-167.

14. Rainey, F. A., M. Dorsch, H. W. Morgan, and E. Stackebrandt. 1992. $16 \mathrm{~S}$ rDNA analysis of Spirochaeta thermophila: its phylogenetic position and implications for the systematics of the order Spirochaetales. Syst. Appl. Microbiol. 15:197-202.

15. Sanders, J. E., and J. L. Fryer. 1986. Genus Renibacterium Sanders and Fryer, $1980,501^{\text {VP }}$, p. $1253-1254$. In P. H. A. Sneath, N. S. Mair, M. E. Sharpe, and J. G. Holt (ed.), Bergey's manual of systematic bacteriology, vol. 2. Williams and Wilkins, Baltimore.

16. Schleifer, K. H., and O. Kandler. 1972. Peptidoglycan types of bacterial cell walls and their taxonomic implications. Bacteriol. Rev. 6:407-477.

17. Stackebrandt, E., C. Koch, O. Gvozdiak, and P. Schumann. Taxonomic dissection of the genus Micrococcus: Kocuria gen. nov., Nesterenkonia gen. nov., Kytococcus gen. nov., Dermacoccus gen. nov., and Micrococcus Cohn 1872 gen. emend. Int. J. Syst. Bacteriol., in press.

18. Stackebrandt, E., and C. R. Woese. 1979. A phylogenetic dissection of the family Micrococcaceae. Curr. Microbiol. 2:317-322.

18a.Weiss, N. Personal communication.

19. Yamada, Y., G. Inouye, Y. Tahara, and K. Kondo. 1976. The menaquinone system in the classification of aerobic gram-positive cocci in the genera Micrococcus, Staphylococcus, Planococcus and Sporosarcina. J. Gen. Appl. Microbiol. 22:227-236. 